\title{
Historia, Etnicidad y Memoria: el proceso de conformación de la identidad indígena en la tribu amiga de Los Toldos (provincia de Buenos Aires)
}

History, Ethnicity and Memory: the making of indigenous identity in the tribe of Los Toldos (province of Buenos Aires)

Ingrid de Jong

\section{(2) OpenEdition}

Journals

\section{Edición electrónica}

URL: http://journals.openedition.org/corpusarchivos/765

DOI: $10.4000 /$ corpusarchivos. 765

ISSN: 1853-8037

Editor

Diego Escolar

\section{Referencia electrónica}

Ingrid de Jong, « Historia, Etnicidad y Memoria: el proceso de conformación de la identidad indígena en la tribu amiga de Los Toldos (provincia de Buenos Aires) », Corpus [En línea], Vol 4, No 1 | 2014, Publicado el 26 junio 2014, consultado el 01 mayo 2019. URL : http://journals.openedition.org/ corpusarchivos/765; DOI : 10.4000/corpusarchivos.765

Este documento fue generado automáticamente el 1 mayo 2019.

Licencia Creative Commons: Atribución-NoComercial 2.5 Argentina (CC BY-NC 2.5 AR) 


\section{Historia, Etnicidad y Memoria: el} proceso de conformación de la identidad indígena en la tribu amiga de Los Toldos (provincia de Buenos Aires)

History, Ethnicity and Memory: the making of indigenous identity in the tribe of Los Toldos (province of Buenos Aires)

Ingrid de Jong

\section{NOTA DEL EDITOR}

DIRECTOR: Lidia Nacuzzi; CODIRECTOR: Claudia Briones

GRADO: Doctorado

INSTITUCION: Facultad de Filosofía y Letras, Universidad de Buenos Aires

FECHA DE DEFENSA: 30/03/2004

CIUDAD: Ciudad Autónoma de Buenos Aires

1 La tesis está disponible en formato PDF en documento anexo

\section{RESÚMENES}

Centrada en la reconstrucción de la trayectoria histórica de la Tribu de Coliqueo en Los Toldos esta tesis pretende aportar al conocimiento de los procesos de conformación de la identidad 
indígena entre los "indios amigos" que se asentaron en la frontera bonaerense a mediados del siglo XIX en relación a los condicionamientos que el marco socioeconómico pampeano planteó a estos grupos con posterioridad a la "Conquista del Desierto" y a lo largo del último siglo. En este sentido, el análisis se dirigió tanto hacia "el discurso sobre la historia" contenido en las configuraciones de memoria sobre la historia local como hacia "la historia del discurso", es decir, hacia la reconstrucción de los contextos históricos en que se fueron conformando los límites y sentidos en relación a la diferencia "indígena" y su relación con lo "nacional", apuntando a encontrar los nexos entre los rasgos del contexto socioeconómico pampeano, las prácticas simbólicas y materiales que articularon las relaciones interétnicas y las formas que adquieren las expresiones y representaciones sobre la identidad y la historia entre las poblaciones indígenas. Concluimos que las recientes expresiones que disputan las representaciones dominantes de la historia local se encuentran vinculadas al impacto de la pérdida del vínculo con la tierra acentuada por los factores que precipitan la migración rural urbana, la nueva realidad común dada por su inserción en barrios periféricos de Los Toldos y la inestabilidad laboral derivada del curso de la economía nacional en la década de 1990, dimensiones que conforman el escenario para una nueva percepción de la situación del conjunto indígena y de su trayectoria histórica.

Centered in the reconstruction of the historical trajectory of the Tribe of Coliqueo in Los Toldos this thesis aims to contribute to the knowledge of the processes of formation of indigenous identity among "indios amigos" settled in Buenos Aires province frontiers by the mid-nineteenth century in relation with the conditions under which the socioeconomic framework after the "Conquest of the Desert" put them by then and throughout the last century. In this sense, the analysis is directed both to "the discourse of history" contained in the memory settings on local history as to "the history of discourse", ie, towards the reconstruction of the historical contexts in which they were forming the boundaries and meanings in relation to the "indigenous" difference and its relation to the "national", aiming to find the links between the features of the Pampean socioeconomic context, the symbolic and material practices that articulated interethnic relations and the ways that expressions and representations of identity and history are shown among indigenous populations. We conclude that recent expressions contesting the dominant representations of local history are linked to the impact of the loss of connection with the land, and are enhanced by precipitating factors for rural-urban migration, the new common reality left by insertion into Los Toldos suburbs and job instability derived from the course of the national economy in the 1990s, dimensions that set the stage for a new perception of the situation of the indigenous group and its historical trajectory.

\section{ÍNDICE}

Keywords: indios amigos, frontier, Buenos Aires province, memory, identity

Palabras claves: frontera, provincia de Buenos Aires, memoria, identidad

\section{AUTOR}

\section{INGRID DE JONG}

Instituto de Cs. Antropológicas, Sección Etnohistoria - Facultad de Filosofía y Letras Universidad de Buenos Aires, Consejo Nacional de Investigaciones Científicas y Técnicas (CONICET), Argentina

Correo electrónico: ildejong@hotmail.com 